\title{
Assessing the Intralobular Ducts in Mouse Mandibular Gland
}

\author{
Bianca MATOSZ ${ }^{1}$, Flavia RUXANDA ${ }^{1 *}$, Vasile RUS ${ }^{1}$ and Viorel MICLĂUȘ ${ }^{1}$ \\ ${ }^{1}$ University of Agricultural Sciences and Veterinary Medicine Cluj-Napoca, Romania \\ *corresponding author: flavia.ruxanda@gmail.com
}

Bulletin UASVM Veterinary Medicine 73(2) / 2016,

Print ISSN 1843-5270; Electronic ISSN 1843-5378

DOI:10.15835/buasvmcn-vm: 12194

\begin{abstract}
Mandibular gland in mouse is composed of a system of extretory ducts, which contains intercalated, granular, intermediary and striated ducts. In order to quantify the types of intralobular ducts, we used five adult male mice, sacrificed by cervical dislocation, after exposure to anesthetic. After euthanasing the animals, the mandibular glands were histologically processed. We sectioned the tissue at $5 \mu \mathrm{m}$ thickness and stained the slides using Goldner's trichrome staining procedure. We captured images on four different microscopic fields for each animal, subsequently counting each type of intralobulary duct. The granular ducts were the most numerous, followed by the intermediary ones and striated ducts with the lowest number.
\end{abstract}

Keywords: granular, mandibular, mouse, percentage, striated.

\section{INTRODUCTION}

Salivary glands are composed of acini and excretory ducts and in mammals present certain structural and functional particularities depending on the type of alimentation. In humans and most of the mammal species, the system of excretory ducts contains intercalated and striated ducts (Yazdani Moghaddam et al., 2009). The mandibular gland in adult mouse, but also in other rodents, has a complex system of intralobular ducts: intercalated, granular, intermediary and striated. The granular ducts are situated between the striated and the intercalated ones, being well expressed in rodents'mandibular gland (Mori et al., 1992; Yazdani Moghaddam et al., 2009) while the intermediary ducts make the transition from the granular ducts to striated ones.

\section{AIMS AND OBJECTIVES}

The aim of our study was quantifying the intralobular ducts in mandibular gland of the mouse.

\section{MATERIALS AND METHODS}

We used five adult male mice from University of Medicine and Pharmacy "Iuliu Haţieganu" Cluj-
Napoca biobase. The subjects were sacrificed after previous exposure to inhalatory anesthesia with Isoflurane. After euthanasia, we harvested the mandibular glands, fixed them in $10 \%$ buffered formalin, dehydrated in ethanol $\left(70^{\circ}, 95^{\circ}\right.$, absolute), clarified in n-butanol and embedded in paraffin. We sectioned the tissue at a $5 \mu \mathrm{m}$ thickness, stained the slides with Goldner's trichrome method and examined them with an Olympus BX41 light microscope, equipped with a digital camera. For assessing the proportion of the different types of intralobular ducts, we captured images on four different microscopic fields using the 20X objective, for each animal. We calculated the average values and percentage for each type of duct out of the total.

\section{RESULTS AND DISCUSSION}

Numerically, intralobular ducts are better represented than the ones from mandibular gland in most of the mammal species. After counting each type of intralobular ducts from 20 fields, we found that granular ducts are the most numerous, with an average of 36.6 ducts/field, followed by intermediary ducts (10.3/field) and striated ones (4.85/field). Expressing these values in 
Tab. 1. Types of ducts in the mandibular gland of the mouse

\begin{tabular}{|c|c|c|c|c|}
\hline \multicolumn{5}{|c|}{ Duct type } \\
\hline Field no. & Granular ducts & Striated ducts & Intermediary ducts & Total \\
\hline 1 & 44 & 5 & 5 & 54 \\
\hline 2 & 32 & 5 & 4 & 41 \\
\hline 3 & 44 & 9 & 8 & 61 \\
\hline 4 & 24 & 3 & 11 & 38 \\
\hline 5 & 31 & 1 & 9 & 41 \\
\hline 6 & 38 & 4 & 10 & 52 \\
\hline 7 & 24 & 2 & 8 & 34 \\
\hline 8 & 51 & 3 & 8 & 62 \\
\hline 9 & 28 & 1 & 16 & 45 \\
\hline 10 & 40 & 7 & 12 & 59 \\
\hline 11 & 43 & 5 & 12 & 60 \\
\hline 12 & 32 & 4 & 12 & 48 \\
\hline 13 & 28 & 9 & 9 & 46 \\
\hline 14 & 39 & 6 & 10 & 55 \\
\hline 15 & 49 & 9 & 11 & 69 \\
\hline 16 & 26 & 3 & 20 & 49 \\
\hline 17 & 33 & 9 & 11 & 53 \\
\hline 18 & 32 & 4 & 12 & 48 \\
\hline 19 & 50 & 5 & 7 & 62 \\
\hline 20 & 44 & 3 & 11 & 58 \\
\hline Total & 732 & 97 & 206 & 1035 \\
\hline Average & 36.6 & 4.85 & 10.3 & 51.75 \\
\hline Minimum & 24 & 1 & 4 & 34 \\
\hline Maximum & 51 & 9 & 20 & 69 \\
\hline St. dev. & 8.738300449 & 2.601113122 & 3.540740333 & 9.233093 \\
\hline$\%$ & 70.72463768 & 9.371980676 & 19.90338164 & 100 \\
\hline
\end{tabular}

percentages, results that $70.73 \%$ from the total ducts present on the field are granular, followed by intermediary ducts $(19.90 \%)$ and striated ducts with the lowest percentage $(9.37 \%)$. In other words, granular ducts are 7,546 times more than the striated ducts and 3,554 times more than the intermediary ones.

Some authors claim that the proportion of granular ducts is much higher in adult mice and especially in males. For example, Smith and Frommer (1975) state that these ducts cover $65 \%$ of the adults' gland in males and $36 \%$ in females (Jayasinghe et al., 1990). Morphologically, the granule size and number in granular ducts increase with the age. The cells lining the granular ducts develop from the ones present in the striated ducts' segment located in the proximity of the intercalated ducts.

\section{CONCLUSION}

The present study highlights the fact that the mandibular gland in adult mouse contains a great number of intralobular ducts, among which granular ones are the most numerous, followed by intermediary ones, while striated ducts are present in smaller numbers.

\section{REFERENCES}

1. Jayasinghe NR, Cope GH, Jacob S (1990). Morphometric studies on the development and sexual dimorphism of the submandibular gland of the mouse. J Anat 172: 115-127.

2. Mori M, Yoshiaki T, Mayuko K (1992). Biologically active peptides in the submandibular gland - role of the granular convoluted tubule. Acta Histochem Cytochem 25(1-2): 325-341.

3. Smith RJ, Frommer J (1975). Quantitative morphology and carbohydrate histochemistry of the mouse submandibular gland following prepubertal castration. American Journal of Anatomy 144: 137-148.

4. Yazdani Moghaddam F, Darvish J, Mahdavi Shahri N, Abdulamir AS, Mousavi M and Daud SK (2009). Comparative histological and histochemical inter-species investigation of mammalian submandibular salivary glands. Res J Appl Sci 4(1): 50-56. 